\title{
Sistem Monitoring Berbasis Internet of Thing (IoT) Untuk Pengendalian Kualitas Air dan Pakan Ikan pada Budidaya sistem Akuaponik
}

\author{
Danih ${ }^{1}$, Sugiyatno ${ }^{1, *}$
}

* Korespondensi: e-mail: sugiyatno@dsn.ubharajaya.ac.id

1 Informatika; Universitas Bhayangkara Jakarta Raya; Jl. Raya Perjuangan Bekasi Utara, Kota Bekasi, 88955882 / 88955871; e-mail: danieaja88@gmail.com, sugiyatno@dsn.ubharajaya.ac.id

Submitted: 27 Maret 2021

Revised: 20 April 2021

Accepted: 7 Mei 2021

Published: 25 Mei 2021

\section{Abstract}

The Internet of Thing (IoT) based monitoring system for controlling routines in aquaponics systems aims to facilitate farmers in carrying out maintenance on cultivation such as feeding fish, checking and controlling water quality and monitoring temperature and humidity. This system uses an android application called Blynk which is connected using an internet connection with NodeMCU which also acts as a brain that processes input from sensors ( $\mathrm{pH}$, Turbidity and DHT11 sensors) and outputs in the form of commands for relays and data sent back to Blynk applications so that the Aquaponics farmers can see the conditions on their farm and control those conditions wherever they are.

Keywords: Aquaponics, DHT11, Internet of Thing (IoT), NodeMCU Blynk, Turbidity.

\section{Abstrak}

Sistem monitoring berbasis internet of thing (IoT) untuk pengendalian rutinitas pada budi daya sistem akuaponik ini bertujuan untuk mempermudah para petani dalam melakukan perawatan pada budi daya seperti pemberian pakan untuk ikan, pengecekan dan pengendalian kualitas air serta monitoring suhu dan kelembaban. Sistem ini menggunakan aplikasi android yang bernama Blynk yang tersambung menggunakan sambungan internet dengan NodeMCU yang bertindak juga sebagai otak yang memproses input dari sensor (sensor $\mathrm{pH}$, Turbidity dan DHT11) dan output berupa perintah untuk relay serta data yang di kirim kembali ke aplikasi Blynk agar para petani akuaponik bisa melihat kondisi pada pertanian mereka serta mengendalikan kondisi tersebut dimanapun mereka berada.

Kata kunci: Akuaponik, DHT11, Internet of Thing (IoT), NodeMCU Blynk, Turbidity. 


\section{Pendahuluan}

Akuaponik adalah salah satu teknik tanam gabungan dari sistem tanah hidroponik dengan teknik pembesaran ikan di kolam (Akuakultur) (Stathopoulo \& B.P, 2018). Saat ini budi daya dengan sistem tanam akuaponik adalah solusi yang tepat untuk masalah berkurangnya lahan budi daya, kelebihan sistem ini petani bisa menghasilkan 2 panen sekaligus yaitu ikan dan sayuran (Dauhan \& E.E., 2014). Pada pengaplikasiannya ikan dan tanaman dibiarkan tumbuh bersama pada satu sistem yang terintegrasi. Beberapa kelemahan sistem akuaponik (Goddek, 2015) seperti pemberian pakan ikan noktunal lebih baik pada malam hari, suhu harus di monitor karena berpengaruh pada kadar $\mathrm{pH}$ air, pengaturan tingkat kadar keasaman air $(\mathrm{pH})$ dalam kolam budi daya, petani harus rutin mengecek kualitas air secara berkala, kekeruhan air juga harus di jaga agar tetap di ambang batas wajar guna menunjang hidup ikan (GA, 2013).

Berdasarkan perangkat yang dibuat ini merupakan mikrokontroler Arduino (Arduino, 2020) yang dapat monitoring serta pengendalian secara manual kualitas air $(\mathrm{pH}$ dan kekeruhan), suhu, kelembaban dan pemberian paka ikan berbasis IOT (Internet of Things) (Oracle, 2020), sistem ini terintegrasi dengan aplikasi yang bernama Blynk (Blynk, 2020) sebagai media pemantauan dan pengendalian dari jarak jauh dengan media internet.

\section{Metode Penelitian}

Dalam melakukan suatu penelitian, diperlukannya suatu metode yang menjadi panduan dasar dalam melakukan penelitian. Pada penelitian ini, metode yang digunakan adalah metode literatur. Metode literatur adalah suatu metode penelitian yang mengumpulkan data dan informasi yang berkaitan dengan penelitian melalui buku,jurnal, internet dan situs-situs internet (Snyder, 2019). Dalam melakukan penelitian peneliti mengumpulkan data dan informasi mengenai budi daya sistem akuaponik di Taman Aquaponic, kemudian Arduino dan sensor yang di perlukan mendukung penyelesaian penelitian yang dilakukan.

Setelah metode literatur dilakukan maka metode selanjutnya adalah membuat analisa perencanaan yang terdiri atas metode pengembangan, pengujian dan analisa akhir. Ketika metode pengembangan sistem telah dilakukan maka langkah yang akan dilakukan selanjutnya adalah pengembangan sistem untuk pengujian hingga perangkat selesai dikerjakan.

Metode pengembangan sistem yang digunakan dalam penelitian ini adalah metode software development life cycle (SDLC) (Pressman, 2010) salah satunya yaitu model prototype. Model prototype prototyping model) dapat digunakan untuk menyambungkan ketidakpahaman client mengenai hal teknis dan memperjelas spesifikasi kebutuhan yang diinginkan client kepada pengembang perangkat lunak. Metode pengembangan prototype (Susanto \& Meiryani, 2019) memiliki beberapa tahapan yang akan dilakukan yaitu analisis kebutuhan, pembuatan prototype, evaluasi prototype, coding sistem pengujian sistem, evaluasi sistem dan penggunaan sistem. 


\subsection{Analisa kebutuhan}

Tahap Analisis kebutuhan merupakan tahap awal dilakukannya penelitian dengan melakukan analisis agar dapat mengetahui seluruh kebutuhan yang diperlukan dalam proses pengembangan sistem. Dalam budi daya sistem akuaponik untuk menghasilkan kualitas ikan dan sayuran yang sangat bagus, memerlukan pengawasan yang intensif seperti pengecekan kualitas air (kadar pH dan kekeruhan air) dan suhu karena merupakan komponen yang sangat krusial untuk sebuah budi daya sistem akuaponik serta pemberian pakan ikan yang juga harus di atur agar tidak mencemari kolam karena sisah pakan ikan. Analisa kebutuhan dapat dijelaskan dalam bentuk aktivitas - aktivitas sistem yang di lakukan pada budi daya sistem akuaponik yang dapat di lihat pada activityd Diagram sistem berjalan.

\subsection{Activity diagram monitoring dan pengendalian kadar $\mathrm{pH}$}

$\mathrm{pH}$ dalam air membutuhkan perhatian khusus karena kadar $\mathrm{pH}$ dalam air dapat berubah-ubah yang di sebabkan perubahan suhu dan juga adanya proses Nitrifikasi yaitu proses pengubahan kotoran ikan (Amonia) menjadi nutrisi (Nitrat) bagi tanaman oleh bantuan bakteri Nitrosomas dan Nitrobakter. Jika tidak jaga dalam batas wajar, maka ikan dan tanaman tidak dapat tumbuh dengan baik bahkan menyebabkan gagal panen. $\mathrm{pH}$ optimal tanaman berkisar antara 5.5 hingga 6.5 sedangkan ikan dapat hidup dalam air dengan pH 6.5 hingga 8.0 dan bakteri yang dibutuhkan dalam proses nitrifikasi tanaman dapat hidup di pH 6 hingga 8.

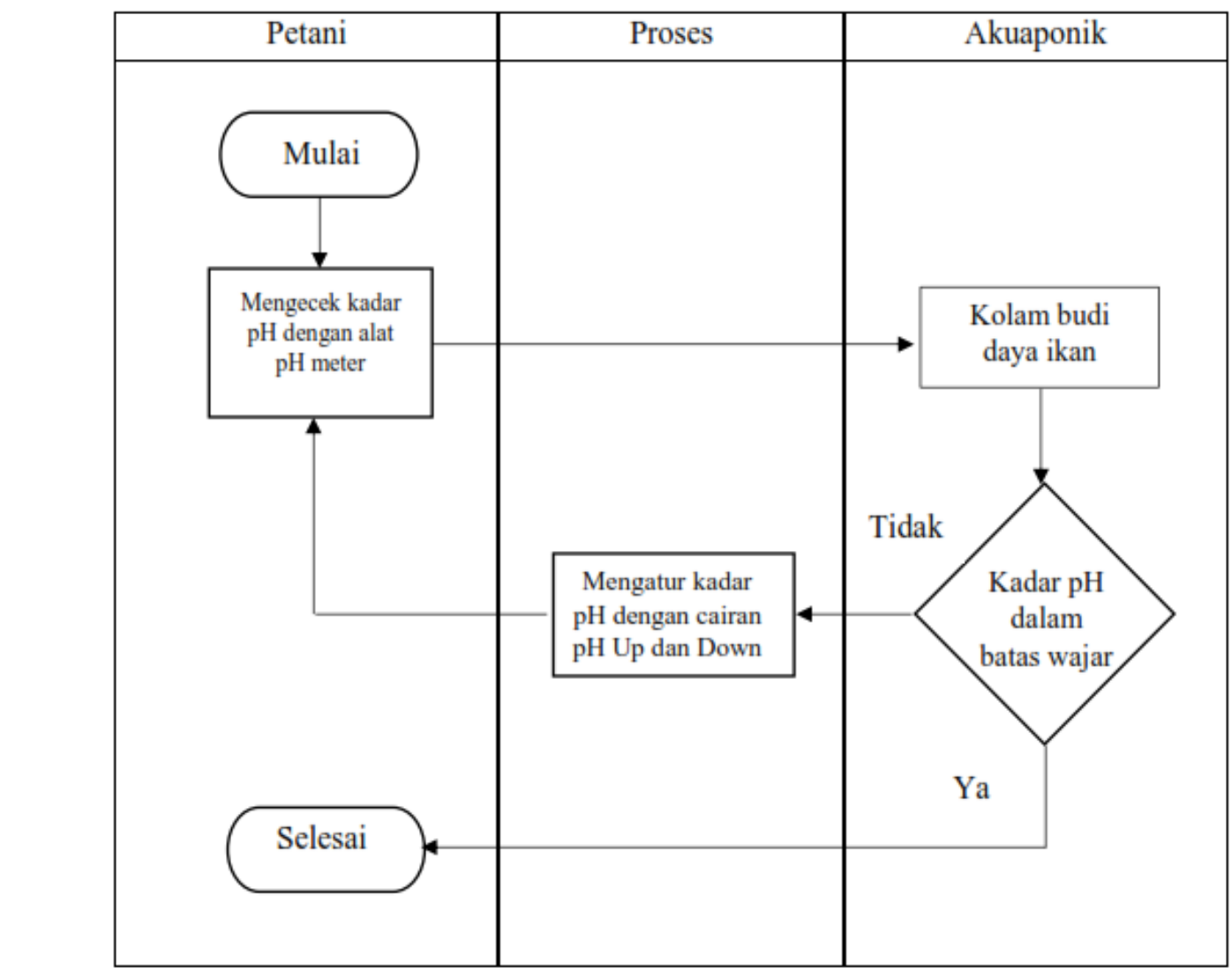

Sumber: Hasil Penelitian (2020)

Gambar 1. Activity Diagram Monitoring dan Pengendalian Kadar pH 


\subsection{Activity diagram pengendalian kekeruhan air kolam}

Kekeruhan dalam kolam membutuhkan perhatian khusus karena kekeruhan air dalam kolam sangat berpengaruh bagi ikan, contohnya jika kekeruhan air dalam kolam dalam batas tidak wajar maka insang ikan akan tertutup lumpur dan berakibat terganggunya perkembangan ikan dan masih banyak hal akan menggangu perkembangan ikan jika kekeruhan ikan tidak wajar. saat ini para petani akuaponik masih menggunakan cara manual dengan bantuan filter, tapi cara itu tidak efisien karna hanya menyaring di permukaan air saja dan tidak menyedot kotoran yang menumpuk di dasar kolam yang disebabkan sisa makanan ikan dan kotoran ikan yang tersisa dari proses nitrifikasi.

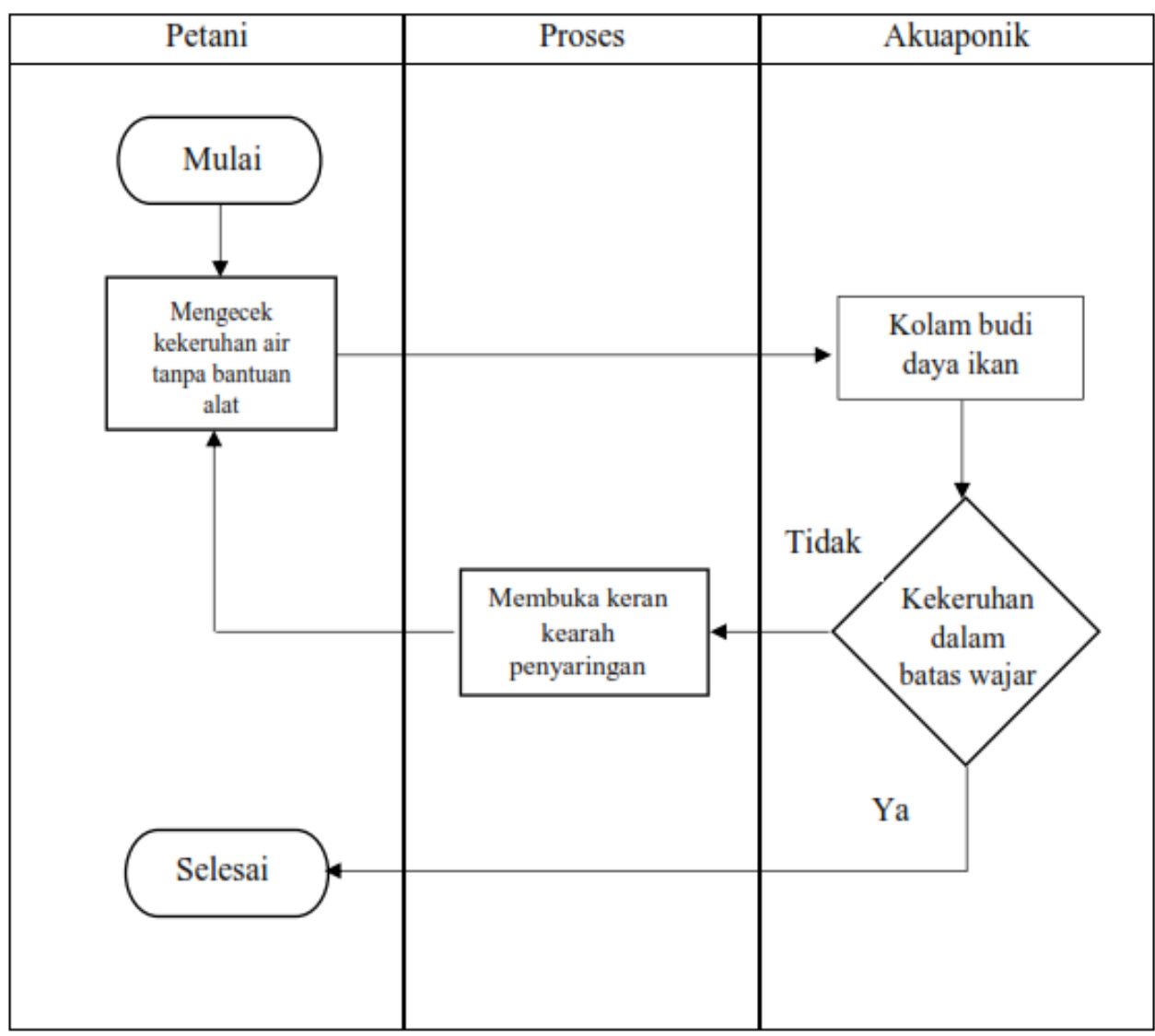

Sumber: Hasil Penelitian (2020)

Gambar 2. Activity Diagram Monitoring Dan Pengendalian Kekeruhan Air

\subsection{Pembuatan prototype}

Setelah mendapatkan serta mengetahui seluruh kebutuhan yang diperlukan dalam pengembangan sistem, maka dilakukan tahap pembuatan prototype. Dalam prototype sistem ini peneliti berencana membuat sebuah alat betujuan untuk membantu para petani sistem Akuaponik dalam rutinitasnya sehari hari, di mulai dari mengecek secara RealTime untuk mengedalikan Kualitas air, suhu dan pemberian pakan ikan dengan memanfaatkan fungsi dari beberapa sensor seperti sensor $\mathrm{pH}$ meter dan turbidity sensor sebagai pengukur kadar $\mathrm{pH}$ dan kekeruhan air serta DHT11 untuk monitoring Suhu dan Kelembaban. Peneliti menggunakan NodeMcu Esp8266 sebagai otak yang memproses dan mengolah data, relay sebagai saklar on- 
off pompa, cairan $\mathrm{pH}$ Up dan Down sebagai pengubah $\mathrm{pH}$ dalam air serta pemanfaatan Modul WiFi ESP8266 yang ada pada NodeMcu sebagai penghubung ke aplikasi Blynk untuk monitoring kondisi dan juga sebagai pengendali kondisi pada budi daya sistem Akuaponik.
INPUT
PROSES
OUTPUT

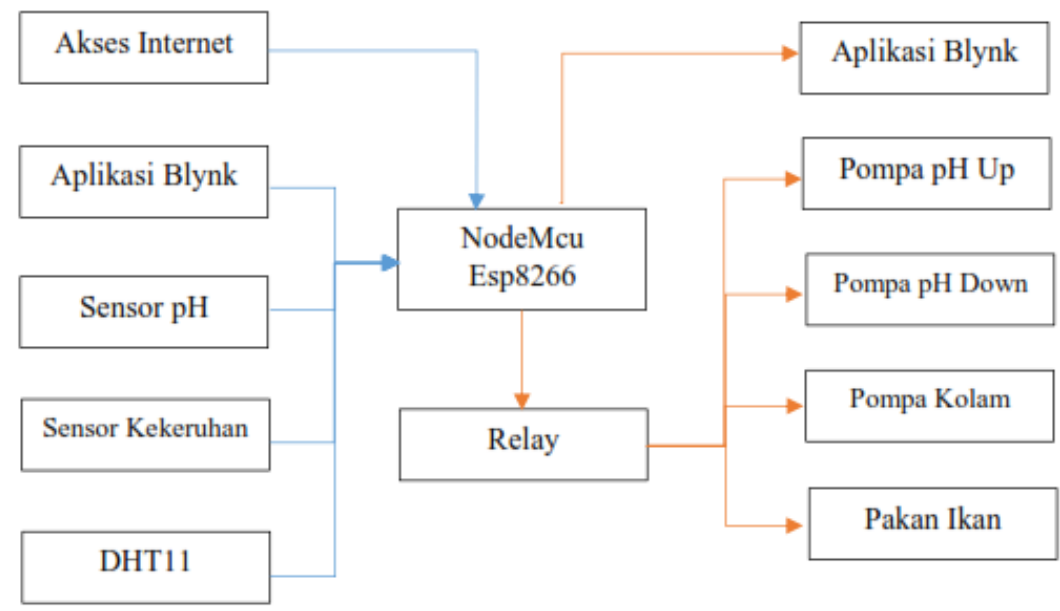

Sumber: Hasil Penelitian (2020)

Gambar 3. Wiring Diagram System

\subsection{Prototype Design}

Design yang dibuat peneliti ini bertujuan untuk memperkenalkan kepada customer sistem yang akan dibuat nantinya, Design Prototype ini bertujuan untuk melihat sistem yang akan berjalan serta melihat kekurangan dan kelebihan yang akan timbul yang akan menjadi acuan peneliti untuk memperbaiki kekurangan sistem yang ada.

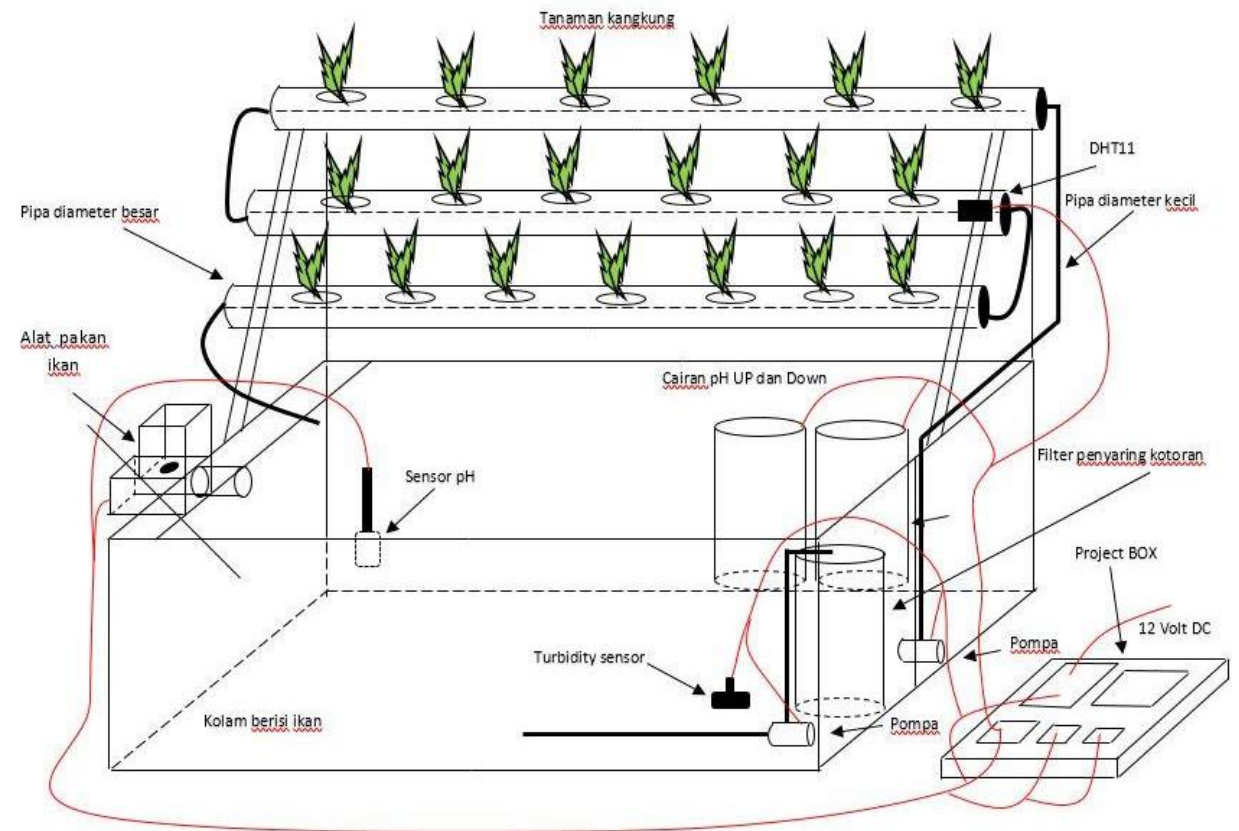

Sumber: Hasil Penelitian (2020)

Gambar 4. Design Prototype 


\section{Hasil dan Pembahasan}

Rancangan untuk membangun Sistem Monitoring berbasis Internet Of Thing (IoT) untuk pengendalian kualitas air dan pakan ikan pada budi daya sistem Akuaponik dalam hal ini dibagi menjadi beberapa bagian seperti Design Sistem, Design Aplikasi, Design Perangkat.

\subsection{Design Arsitektur Sistem}

Arsitektur Sistem merupakan gambaran dari keseluruhan rangkaian dalam pembangunan sistem monitoring berbasis Internet Of Thing (IOT) untuk pengendalian kualitas air dan pakan ikan pada budi daya sistem Akuaponik

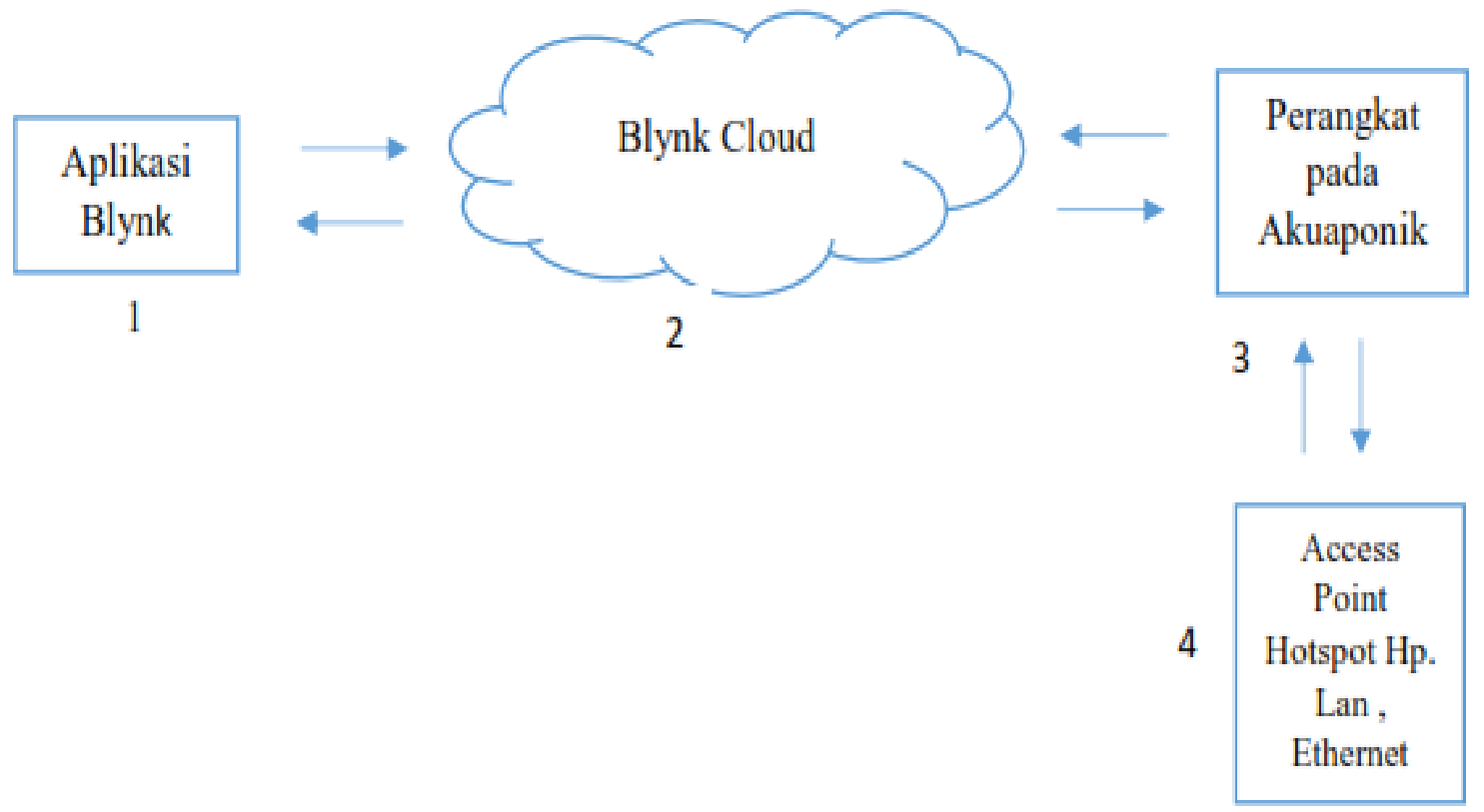

Sumber: Hasil Penelitian (2020)

\section{Gambar 5. Asitektur Sistem}

Gambar 5 merupakan arsitektur sistem yang menghubungkan aplikasi Blink yang ada pada Cloud yang telah ada dan terhubung dengan perangkat Akuaponik yang dapat diakses melalui Access point hotspot. Berikut ini penjelasan dari gambar 5 yang diuraikan dalam tabel 1 .

Tabel 1 Asitektur Sistem

\begin{tabular}{lll}
\hline No & Yang Terlibat & Penjelasan \\
\hline 1 & $\begin{array}{l}\text { Aplikasi blynk [1] ke Blynk } \\
\text { Server [2] }\end{array}$ & $\begin{array}{l}\text { Aplikasi mengakses program Library Blnyk untuk tersambung ke } \\
\text { blynk server dengan media Internet }\end{array}$ \\
\hline 2 & $\begin{array}{l}\text { Perangkat [3] ke Acces Point } \\
\text { [4] ke Blynk Server [2] }\end{array}$ & $\begin{array}{l}\text { Perangkat pada budi daya akuaponik yang sudah terintegrasi } \\
\text { dengan sensor sebagai input dan relay sebagai output akan } \\
\text { tersambung ke internet melalui accesspoint atau sumber internet, } \\
\text { (Username dan Password akses yang sudah dimasukan pada } \\
\text { program) saat tersambung ke Internet Perangkat akan } \\
\text { mengakses Library Blnyk dan Auth Token sebagai alamat akses } \\
\text { ke aplikasi Blynk }\end{array}$ \\
\hline 3 & $\begin{array}{lll}\text { Aplikasi Blynk [1] ke Blynk } \\
\text { Server [2] ke Perangkat [3] }\end{array}$ & $\begin{array}{l}\text { Saat semua tersambung, maka aplikasi Blynk akan mempunyai } \\
\text { akses penuh pada perangkat yang disini berisi sensor dan relay, } \\
\text { sehingga aplikasi Blnyk dapat memonitor dan mengendalikan } \\
\text { perangkat dari jarak jauh dengan media internet }\end{array}$ \\
\hline Sumber: Hasil Penelitian (2020) &
\end{tabular}




\subsection{Perancangan perangkat keras}

Pada gambar 6 terdiri dari beberapa rangkaian sebagai berikut (a) 3 buah modul stepdown dirangkai paralel untuk mensupply listrik sebesar 5 volt ke seluruh bagian komponen yaitu NodeMCU, sensor pH, dan Motor; (b) Pin data dari sensor $\mathrm{pH}$ dihubungkan ke pin $\mathrm{A} 0$ NodeMCU lalu pin VCC dan GND dihubungkan langsung ke modul stepdown; (c) 4 pin data Relay di hubungkan ke pin D NodeMCU lalu pin VCC relay dihubungkan ke modul stepdown sedangkan pin GND dihubungkan ke pin G NodeMCU; (d) Pin data modul turbidity dihubungkan ke pin D2 NodeMcu lalu pin VCC serta GND dihubungkan ke pin 3.3V dan GND; (e) Pin data DHT11 dihubungkan ke pin D4 NodeMCU lalu pin VCC serta GND dihubungkan ke pin 3.3V dan GND; (f) Kabel 5V dari modul stepdown dihubungkan ke NO relay dan kabel GND dari stepdown dihubungkan ke motor lalu kabel positif motor dihubungkan ke 0 relay.

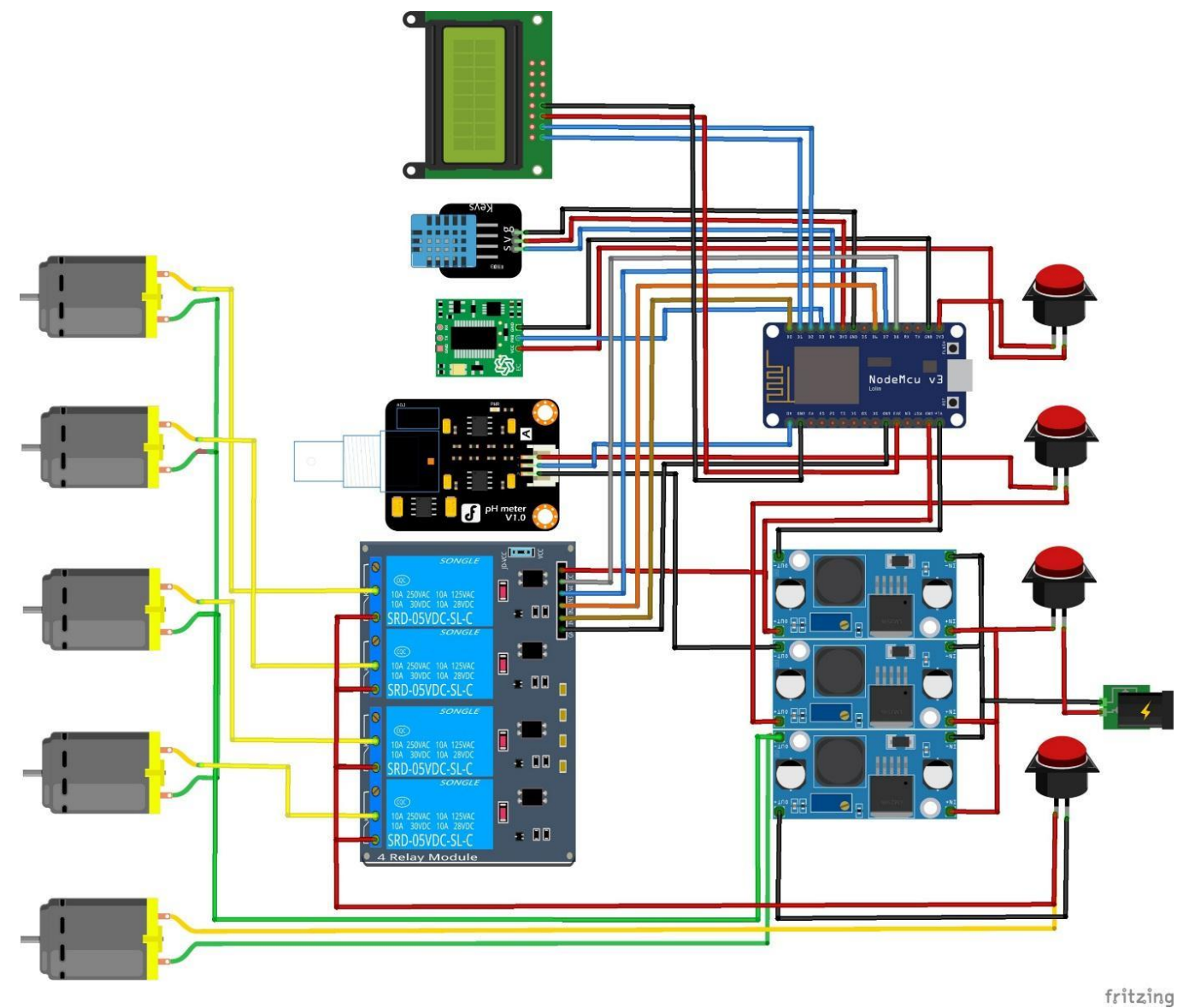

Sumber: Hasil Penelitian (2020)

Gambar 6. Wiring diagram perangkat dan penjelasannya.

\subsection{Perancangan keseluruhan Prototype}

Pada gambar 7 perancangan eselukruhan prototype terdapat perangkat pengendali yang bertugas memproses data yang dari sensor, di kiri gambar terdapat mesin pakan ikan di dalam kolam terdapat pompa penyaringan, sirkulasi dan sejumlah sensor, di atas gambar terdapat sensor DHT11 dan dibelakang terdapat tempat penyimpanan cairan $\mathrm{pH}$. Design 
prototype ini dibuat peneliti agar memudahkan Customer melihat keseluruhan sistem yang ada, jika nanti akan dibuat sistem sebenarnya yang lebih besar.

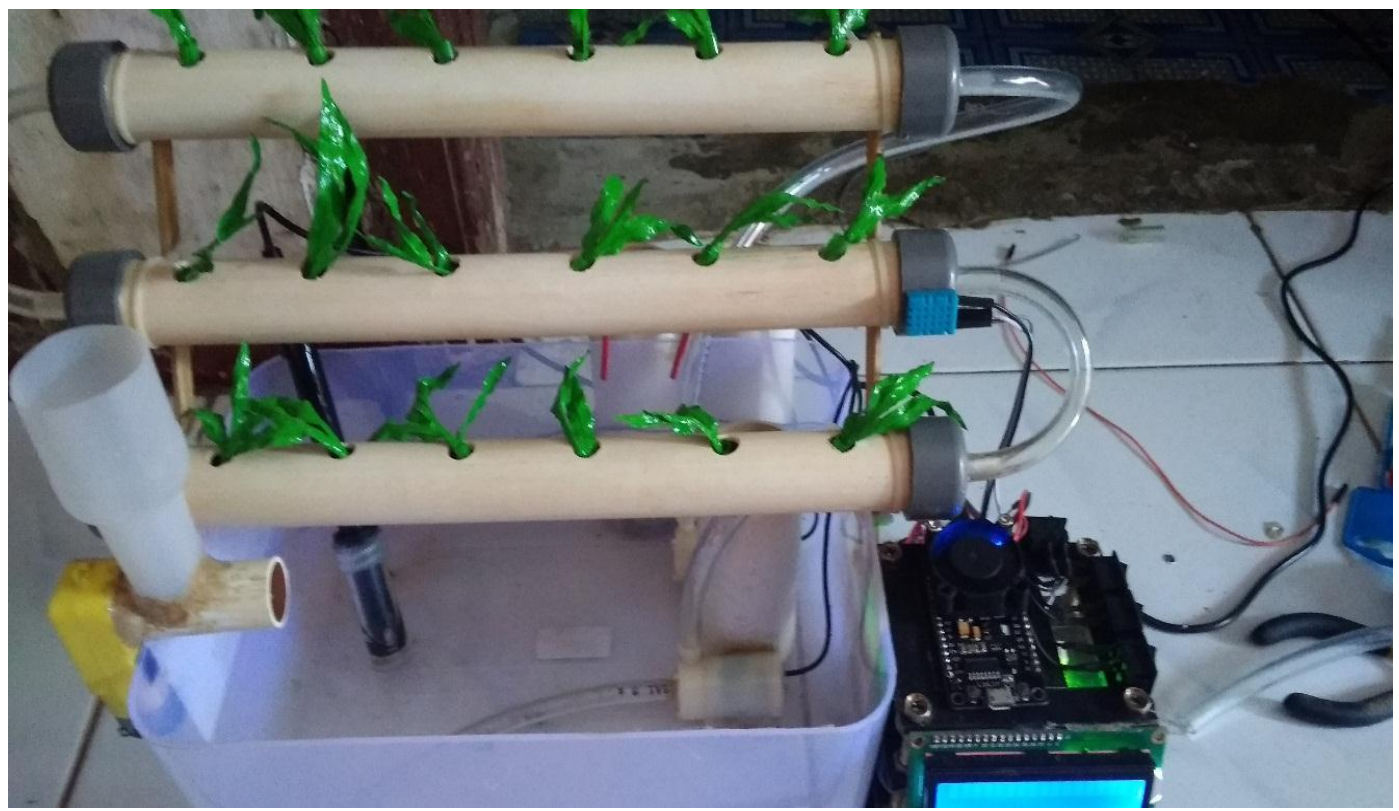

Sumber: Hasil Penelitian (2020)

\subsection{Pengujian sistem}

Gambar 7. Perancangan Keseluruhan Prototype

Tahap Pengujian ini dimaksudkan untuk menjelaskan sistem yang berkerja pada Prototype yang dibuat oleh peneliti, data yang dihasilkan dari pengujian ini akan menjadi bahan acuan untuk membuat sistem yang sebenarnya dan juga untuk capaian dalam penelitian pembuatan produk.

\subsubsection{Pengujian NodeMCU terhadap aplikasi blynk}

Pengujian ini dilakukan untuk mengetahui saat NodeMCU tersambung dengan blynk server dan aplikasi blynk dismartphone melalui internet, adapun proses lama penyambungan dipengaruhi oleh kekuatan sinyal di daerah tempat pengujian.

Tabel 2. Proses Penyambungan Perangkat ke Server Blnyk

\begin{tabular}{ccc}
\hline Pengujian & Lama tersambung & Kesimpulan \\
\hline NodeMCU ke server Blnyk & $4-10$ detik & berhasil \\
\hline Sumber: Hasil Penelitian (2020) & &
\end{tabular}

\subsubsection{Pengujian Sensor pH}

Pengujian ini dilakukan untuk mengetahui ouput yang dihasilkan oleh sensor $\mathrm{pH}$ yang di terima oleh NodeMcu yang ditampilan diserial monitor, pengujian ini menggunakan $\mathrm{pH}$ buffer dengan kadar 4.01, 6.86, dan 9.18

Tabel 3. Pembacaan Sensor $\mathrm{pH}$ terhadap kadar $\mathrm{pH}$

\begin{tabular}{|c|c|c|}
\hline Pengujian & Seharusnya & Kesimpulan \\
\hline 05.00 & 04.01 & Kalibrasi belum akurat, \\
\hline 07.40 & 6,86 & kesalahan pembacaan rata rata \\
\hline 11.18 & 09.18 & $<1-2$ \\
\hline
\end{tabular}

Sumber: Hasil Penelitian (2020) 


\subsubsection{Pengujian Turbidity sensor}

Pengujian ini dilakukan untuk mengetahui output dari pembacaan sensor, di sini peneliti memprogram sensor agar menampilkan data diserial monitor "Air kotor" saat probe di celupkan di air kotor dan "Air Jernih" saat di celupkan di air jernih.

Tabel 4. Pembacaan Sensor Turbidity

\begin{tabular}{cccc}
\hline Pengujian & Lcd & Lcd Blynk & Kesimpulan \\
\hline Pada air kotor & Air kotor & Air kotor & Berhasil \\
\hline Pada air jernih & Air Normal & Air Normal & Berhasil \\
\hline
\end{tabular}

Sumber: Hasil Penelitian (2020)

\subsubsection{Pengujian DHT11}

Pengujian ini untuk mengetahui nilai suhu dan kelembaban dari sensor DHT11 yang akan ditampikan di aplikasi blynk, lama pengiriman data di pengaruhi sinyal di daerah pengujian.

Tabel 5. Pembacaan Sensor DHT11

\begin{tabular}{lllll}
\hline Pengujian & & Lama pengiriman & Seharusnya & Kesimpulan \\
\hline Suhu & 31 Celcius & 5 detik & 30 Celcius & Belum akurat $<1$ \\
\hline Kelembaban & $65 \%$ & 7 detik & $50 \%$ & Belum akurat \\
& & & $<15 \%$ \\
\hline
\end{tabular}

Sumber: Hasil Penelitian (2020)

\subsubsection{Pengujian Relay}

Pengujian ini untuk mengetahui lamanya relay menerima data dari NodeMCU yang dikendalikan oleh aplikasi blynk, relay tersebut sebagai switch atau saklar untuk menghidupkan Motor DC pada perangkat, lama pengiriman dipengaruhi oleh sinyal di daerah pengujian

\begin{tabular}{ccccc}
\multicolumn{5}{c}{ Tabel 6. Pengujian Relay } \\
\hline Pengujian & Aplikasi Blynk & Pengiriman data & Seharusnya & Kesimpulan \\
\hline $\mathrm{pH} \mathrm{Up}$ & Push Button pH Up & 2 Detik & Relay ON lalu OFF & Berhasil \\
\hline $\mathrm{pH}$ Down & Push Button pH Down & 3 Detik & Relay ON lalu OFF & Berhasil \\
\hline Pakan ikan & Button Pakan ikan & 2 Detik & $\begin{array}{c}\text { Relay ON 4 Detik } \\
\text { lalu OFF }\end{array}$ & Berhasil \\
\hline Penyaringan & $\begin{array}{c}\text { Swicth ON Button } \\
\text { Penyaringan }\end{array}$ & 2 Detik & Relay ON & Berhasil \\
\cline { 2 - 5 } & $\begin{array}{c}\text { Switch OFF Button } \\
\text { Penyaringan }\end{array}$ & 2 Detik & Relay OFF & Berhasil \\
\hline Sumber: Hasil Penelitian (2020) & & &
\end{tabular}

\section{Kesimpulan}

Berdasarkan data-data yang telah diambil dalam penelitian ini, dapat ditarik kesimpulan yaitu perangkat yang dibuat dapat monitoring serta pengendalian secara manual kualitas air ( $\mathrm{pH}$ dan kekeruhan), suhu, kelembaban dan pemberian pakan ikan berbasis IOT (Internet of Things) dan sistem terintegrasi dengan aplikasi yang bernama Blynk sebagai media pemantauan dan pengendalian dari jarak jauh dengan media internet. Namun perlu keakuratan kalibrasi untuk sensor $\mathrm{pH}$ dan Turbidity agar mendapatkan nilai ukur yang akurat mengingat nilai sensor tersebut sangat berpengaruh untuk kelangsungan hidup ikan dan tanaman dan 
membuat perhitungan banyakanya pakan yang akan keluar ke dalam kolam pada sistem pakan ikan agar kebutuhan makanan ikan lebih optimal dan tepat takarannya.

\section{Daftar Pustaka}

Arduino. (2020). Arduino. Https://Www.Arduino.Cc/: https://www.arduino.cc/

Blynk. (2020). Blynk. Https://Blynk.lo/: Https://Blynk.lo/. https://blynk.io/: https://blynk.io/

Dauhan, R., \& E.E. (2014). Efektivitas Sistem Akuaponik dalam Mereduksi Konsentrasi Amonia Pada Sistem Budidaya Ikan. Rekayasa Dan Teknologi Budidaya Perairan, 1-6.

GA, S. S. (2013). Analisis Penerapan Biofilter Dalam Sistem Resirkulasi Terhadap Mutu Kualitas Air Budidaya Ikan Sidat (Anguilla bicolor). Jurnal Gamma, 86-97.

Goddek, B. D. S. (2015). Challenges of Sustainable and Commercial Aquaponics. Sustainability, 4200-4224.

Oracle. (2020). Oracle. Https://Www.Oracle.Com/Internet-of-Things/What-Is-Iot/. https://www.oracle.com/internet-of-things/what-is-iot/

Pressman, R. S. (2010). Software Engineering : a practitioner's approach. New. McGraw-Hill.

Snyder, H. (2019). Literature review as a research methodology: An overview and guideline. Journal of Business Research, 332-339. www.elsevier.com/locate/jbusres

Stathopoulo, P., \& B.P, -M. (2018). Aquaponics: A Mutually Beneficial Relationship of Fish, Plants And Bacteria. Hydromedit, 1-5.

Susanto, A., \& Meiryani. (2019). System Development Method with The Prototype. International Journal of Scientific \& Technology Research, 141-144. 